\title{
New taxa and a new combination in the genus Cotyledon
}

\author{
H. R. TÖLKEN*
}

\begin{abstract}
Five new species and one variety are described and the combination rotyledon tomentosa Harv. subsp. ladismithiensis ( $V$. Poelln.) Toelken is effected. The following new names are published; $C$. sulphurea Toelken, $C$. occultans Toelken, $C$. similis Toelken, $C$. viridiflorum Toelken, $C$. hallii Toelken and $C$. pygmaea Barker var. tenuis Toelken.
\end{abstract}

\section{RESUME}

NOUVEAU TAXA ET NOUVELLE COMBINAISON DANS LE GENRE COTYLEDON

On décrit cinq espèces et une variété nouvelles. La combinaison Cotyledon tomentosa Harv. subsp. ladismithiensis (V.Poelln.) Toelken est opérée. Les nouveaux noms publiés sont: C.sulphurea Toelken, C.occultans Toelken, C.similis Toelken, C.viridiflorum Toelken, C.hallii Toelken et C.pygmaea Barker var. tenuis Toelken.

Recent collecting has added more information to the knowledge of some rare species of Cotyledon from the north-western Cape Province, so that these can now be described. This has also allowed a re-evaluation of the delimitation of other species, which were previously differently interpreted.

1. Cotyledon sulphurea Toelken, sp. nov. a C. occultante foliis glabris, florescentia praecociore et ovulis ovatis differt.

Herbae perennes tuberibus subterraneis ramosis usque ad $10 \mathrm{~cm}$ longis, ramis succulentis laevibus pauciramosis et rare $2 \mathrm{~cm}$ longioribus. Folia alterna, oblanceolata vel spathulata, $0,5-2,5 \mathrm{~cm}$ longa, $0,2-$ $0,5 \mathrm{~cm}$ lata, cuneata, plerumque obtusa, dorsoventraliter, complanata, leviter sulcata supra et convexa subtus, glabra sed cellulis pustuliformibus, succulenta, viridia. Inflorescentia thyrsus corymbiformis 1-4 dichasiis patentibus, pedunculo rigido $1-3(-5) \mathrm{cm}$ longo et tecto pilis glandulosis, pedicello $0,4-0,8 \mathrm{~cm}$ longo et tecto pilis glandulosis, bracteis lanceolatis deciduis. Sepala triangulari-lanceolata, 0,35-0,45 cm longa, acuta, tecta sparsim pilis glandulosis patentibus, succulenta, flavo-virentia. Petala oblonga, 1,3-1,5 $\mathrm{cm}$ longa, acuta, connata in tubo $0,8-1 \mathrm{~cm}$ longo, tecta plus minusve etiam pilis glandulosis patentibus extus et pilis aliquot tenuis intus praecipue tubi petalorum in partibus inferis, sulphurea. Stamina $1-1,2 \mathrm{~cm}$ longa et aequilonga, antheris $0,1-0,12 \mathrm{~cm}$ longis et filamentis rectis pilis patentibus praecipue in partibus quibus connatis petalorum tubo. Squamae oblongae $0,1-0,13 \times 0,02-0,04 \mathrm{~cm}$, plus minusve emarginatae, leviter succulentae, flavae. Carpella ovariis gracilibus gradate constricta ad stylos erectos et stigmatibus terminalibus; ovarium 10-14 ovulis ovatis sine porcis verticalibus.

Type: Cape: near Pofadder, Tölken 3676A (BOL, holo.!).

Perennial with branched underground tubers up to $10 \mathrm{~cm}$ long, with fleshy glabrous stems little branched and rarely longer then $2 \mathrm{~cm}$. Leaves alternate, oblanceolate to spathulate, $0,5-2,5 \mathrm{~cm}$ long, $0,2-$ $0,5 \mathrm{~cm}$ broad, cuneate, usually obtuse, dorsiventrally compressed and slightly grooved above and convex below, succulent, glabrous but with some large bulging epidermal cells, green. Inflorescence a flattopped thyrse with one to several spreading monochasia, with wiry peduncle $1-3(-5) \mathrm{cm}$ long and covered with glandular hairs, with pedicels 0,4

* Botanical Research Institute, Department of Agricultural Technical Services, Private Bag X101, Pretoria
$0,8 \mathrm{~cm}$ long and covered with glandular hairs, with lanceolate bracts deciduous. Sepals triangular-lanceolate, $0,35-0,45 \mathrm{~cm}$ long, acute, sparsely covered with glandular hairs, succulent, yellowish-green. Petals oblong 1,3-1,5 cm long, acute, fused into a tube $0,8-1 \mathrm{~cm}$ long, more or less evenly covered with spreading glandular hairs on the outside and with few fine hairs on the inside mainly where the filaments are fused to the petal-tube, sulphur-yellow. Stamens $1-1,3 \mathrm{~cm}$ long and all of equal length, with anthers $0,1-0,12 \mathrm{~cm}$ long, with straight filaments, with scattered hairs mainly where fused to the petal-tube. Squama' oblong 0,1-0,13 $\times 0,02-0,04 \mathrm{~cm}$, more or less emarginate, slightly succulent, yellow. Carpels with slender ovaries gradually constricted into erect styles with terminal stigmas; ovary with $24-40$ ovate ovules without distinct vertical ridges.

This species is usually found on quartzite gravel on the lower slopes of hills and has been recorded only from the vicinity of Pofadder, but here it is locally common. It flowers during November and December, a distinguishing feature between this species and $C$. occultans.

CAPE,-2919 (Pofadder): $4 \mathrm{~km}$ N.E. of Pofadder (-AB), Horn 1011 (NBG); Horn sub NBG 87361 (NBG); near Pofadder (-AB), Tölken 3676 A (BOL); Wisura 196I (NBG); 11 km S.E. of Pofadder (-AB), Tölken 3679 A (BOL).

2. Cotyledon occultans Toelken, sp. nov. a $C$. sulphurea foliis paene orbicularibus quibus tectis pilis glandulosis et florescentia serotinioribus; a $C$. pygmaea ramo brevissimo et trichotomatibus unicellularibus.

Herbae perennes tuberibus subterraneis pauciramosis usque ad $6 \mathrm{~cm}$ longae, ramis laevibus pauciramosis et usque ad $1 \mathrm{~cm}$ longis. Folia alterna, spathulata vel orbicularia, $0,4-1,2 \mathrm{~cm}$ longa, $0,3-1,4 \mathrm{~cm}$ lata, cuneata vel paene petiolata, obtusa, dorsiventraliter complanata et leviter sulcata supra, tecta dense trichotomatibus erectis obtusis, succulenta, atrovirentia. Inflorescentia thyrsus $1(-3)$ monochasiis $1-3$ floribus, pedunculo rigido $0,8-1,5 \mathrm{~cm}$ longo et tecto pilis glandulosis, pedicello $0,5-1,3 \mathrm{~cm}$ longo et tecto pilis glandulosis, bracteis lanceolatis caducis. Sepala triangulari-lanceolata, $0,2-0,3 \mathrm{~cm}$ longa, acuta, tecta pilis glandulosis, succulenta, viridia. Petala oblonga, $1-1,2 \mathrm{~cm}$ longa, acuta, connata in tubo $0,6-0,8 \mathrm{~cm}$ longo, plus minusve etiam tecta pilis glandulosis extus et pilis aliquot tenuibus intus praecipue in partibus inferis tubi petalorum. Stamina $1,1-1,4 \mathrm{~cm}$ longa et aequilonga, antheris $0,1-0,12 \mathrm{~cm}$ longis, filamentis rectis pilis tenuibus sparsis praecipue in partibus quibus connatis petalorum tubo. Squamae oblongae, $0,11-0,13 \times 0,02-0,04 \mathrm{~cm}$, plerumque plus 
minusve emarginatae, succulentae, flavae. Carpella ovariis gracilibus gradate constrictis ad stylos erectos stigmatibus terminalibus; ovarium 10-14 ovulis ovatis sed lateriobus ad lateres et porcis verticalibus.

Type: Cape, near Bitterfontein, H. Hall 4289 (PRE, holo.!; NBG).

Perennial with little branched underground tubers up to $6 \mathrm{~cm}$ long, with short glabrous stems little branched and up to $1 \mathrm{~cm}$ long. Leaves alternate, spathulate or orbicular, 0,4-1,2 cm long, 0,3-1,4 cm broad, cuneate or almost petiolate, obtuse, dorsiventrally compressed and slightly grooved above, densely covered with blunt erect trichomes, deep green. Inflorescence a thyrse with $\mid(-3)$ monochasia, each with $1-3$ flowers, with wiry peduncle $0,8-1,5 \mathrm{~cm}$ long and covered with glandular hairs, with pedicels $0.5-1,3 \mathrm{~cm}$ long and covered with glandular hairs, with lanceolate deciduous bracts. Sepals triangularlanceolate, $0,2-0,3 \mathrm{~cm}$ long, acute, covered with glandular hairs, succulent, green. Petals oblong, $1-1,2 \mathrm{~cm}$ long, acute, fused into a tube $0,6-0.8 \mathrm{~cm}$ long and more or less evenly covered with spreading glandular hairs on the outside and with a few fine hairs on the inside mainly where the filaments are fused to the petal tube, pale yellow or yellowishgreen. Stamens $1,1-1,4 \mathrm{~cm}$ long and about equally long, with anthers $0,1-0,12 \mathrm{~cm}$ long, with straight filaments with fine hairs mainly where fused to the petal tube. Squamae oblong, $0,11-0,13 \times 0,02-0,04$ $\mathrm{cm}$, usually more or less emarginate, fleshy, yellow. Carpels with slender ovaries gradually constricted into erect styles with terminal stigmas; ovary with 8-20 ovules almost dumbell-shaped and with distinct vertical ridges.

So far this small Cotyledon has been recorded from quartzite gravel near Bitterfontein and Steinkopf, but the fact that these two localities are so far away from each other suggests that the species is probably widely distributed over the little known eastern foothills of the Kamiesberg. $\mathrm{Mr} \mathrm{H}$. Hall, the very observant collector, was the first to draw attention to this small plant. In addition, the species flowers in February and March, the driest period in the Namaqualand, so that it is rarely seen in flower.

CAPE.-2917 (Springbok): $11 \mathrm{~km} \mathrm{S.} \mathrm{of} \mathrm{Steinkopf} \mathrm{(-BD),}$ Tölken 4272 (BOL). 3118 (Vanrhyrsjorp): near Bitterfontein (-AB), H. Hall 3960 (PRE): 4289 (NBG, PRE).

3. Cotyledon pygmaea Barker in Flow. Pl. S. Afr. 10: t. 396 (1930). Type: Cape, Vanrhynsdorp, Vigne sub NBG $2267 / 29$ (K, holo!).

\section{var. pygmaea.}

Stems robust and usually $(0,4-) 0,5-1 \mathrm{~cm}$ in diameter, with pale yellow rarely greyish bark which is smooth or peeling in older plants. Leaves densely covered with heart-shaped trichomes. Squamae transversely oblong to square, $0,08-0,1 \times 0,1-0,13 \mathrm{~cm}$.

Characteristic of $C$. plgmaea are the multicellular trichomes which consist of two larger basal cells and a smaller glandular cell at the apex. The basal cells are bulging which gives them the heart-shaped appearance at least on the leaves of var. pygmaea. The petals are covered with trichomes with oblong basal cells and the terminal cell is very small. The latter type of trichomes are found on all parts of the plants of var. tenuis.

Although extreme forms of the two varieties may differ in several characters such as the diameter of stems and their bark, a considerable range of variation has been recorded and both varieties were found near Koekenaap. The plant of the typical variety (Hall sub NBG 587/54) from that area shows somewhat intermediate characters, but its pollen shows no abnormality to indicate that the two varieties hybridize in this region.

var. tenuis Toelken, var. nov., a var. pygmaea squamis oblongis differt.

Caules tenues $0,2-0,3(-0,4) \mathrm{cm}$ in diametro, cortice griseo plus minusve porcata et non chartaceo. Folia trichotomibus oblongis sparsim tecta. Squamae oblongae $0,09-0,12 \times 0,04-0,06 \mathrm{~cm}$.

Type: Cape, near Holrivier Station, H. Hall 3925 (PRE, holo.!: NBG!).

Stems slender $0.2-0.3(-0.4) \mathrm{cm}$ in diameter, with grey bark more or less ridged and not peeling. Leaves sparsely covered with erect oblong trichomes. Squamae oblong 0,09-0,12×0,04-0,06 cm.

CAPF.-3118 (Vanrhynsdorp): near Holrivier Station (-AD), Hall 3925 (NBG, PRE): 4273 (PRE): Koekenaap (-CB), Hall 2786 (NBG); Hall sub NBG $72 / 56$ (NBG); Vanrhynsdorp (-DB); Compton et al sub NBG $842 a+48$ (NBG).

4. Cotyledon similis Toelken, sp. nov. a C.pygmaea foliis glabris et pilis longissimis in fauce tubi petalorum differt.

Herbae perennes tuberibus subterraneis pauciramosis usque ad $5 \mathrm{~cm}$ longis, caulibus erectis rare remosis et usque ad $12 \mathrm{~cm}$ longis et usque ad $0,4 \mathrm{~cm}$ in diametro, griseis et porcis nigris verticalibus. Folia alterna, elliptica vel oblonga, $0,5-1,3 \mathrm{~cm}$ long, $0,2-$ $0,4(-0,5) \mathrm{cm}$ lata, acuta vel obtusa, teretia vel leviter complanata, glabra sed cellulosis pustuliformibus, viridia et saepe rufo-striata. Inflorescentia monochasium $1(-3)$ floribus, pedunculo glabro $0,8-3 \mathrm{~cm}$ longo, pedicello glabro $0,4-0,6 \mathrm{~cm}$ longo, bracteis lanceolatis deciduis. Sepala triangulari-lanceolata, $0,15-0,25 \mathrm{~cm}$ longa, acuta, glabra, succulenta, viridia. Petala oblonga, $0,8-1 \mathrm{~cm}$ longa, acuta, connata in tubo $0,6-0,8 \mathrm{~cm}$ longo, extus glabra et intus pilis longis tenuis praecipue in fauce tubi petalorum, pallide flavo-virentia vel eburnea. Stamina $0,7-1 \mathrm{~cm}$ longa et aequilonga, antheris $0,08-0,1 \mathrm{~cm}$ longis, filamentis rectis pilis patentibus praecipue in partibus quibus connatis tubo petalorum. Squamae anguste oblongae, $0,12-0,14 \times 0,02-0,03 \mathrm{~cm}$, plerumque penitus emarginatae, leviter succulentae, croceae ad flavam. Carpella ovariis gracilibus gradate constricta ad stylos erectos et stigmatibus terminalibus; ovarium $10-14$ ovulis ovatis sed latioribus ad lateres et porcis verticalibus.

TYPE: Cape, N. of Grootmis, Wisura 1303 (NBG, holo!).

Perennial with branched underground tubers up to $5 \mathrm{~cm}$ long, each with an erect stem; stems rarely branched, up to $12 \mathrm{~cm}$ long and up to $0,4 \mathrm{~cm}$ in diameter, grey with black vertical ridges. Leaves alternate, elliptic to oblong $0,5-1,3 \mathrm{~cm}$ long, $0,2-0,4$ $\mathrm{cm}$ broad, acute or obtuse, terete or almost so, glabrous but with irregularly bulging epidermal cells, green, often with reddish-brown stripes. Inflorescence a monochasium with 1 (-3) flowers, with glabrous peduncle $0,8-3 \mathrm{~cm}$ long, with glabrous pedicels $0,4-0,6 \mathrm{~cm}$ long. with deciduous lanceolate bracts. Sepals triangular-lanceolate, $0,15-0,25 \mathrm{~cm}$ long, acute, glabrous, succulent, green. Petals oblong, $0,8-1 \mathrm{~cm}$ long, acute, fused into a tube $0,6-0,8$ $\mathrm{cm}$ long, glabrous on the outside and with long fine hairs in the throat of the petal tube, pale yellowish-green to cream. Stamens $0,7-1 \mathrm{~cm}$ long and all about the same length, with anthers $0,08-0,1 \mathrm{~cm}$ long, with straight filaments with spreading hairs mainly where fused to the petal tube. Squamae narrowly oblong, $0,12-0,14 \times 0,02-0,03 \mathrm{~cm}$, usually deeply emarginate, slightly fleshy, orange to yellow. 
Carpels with slender ovaries gradually constricted into erect styles and terminal stigmas; ovary with 10-14 ovules almost dumbell-shaped and with vertical ridges.

Plants of this species were found either in eastfacing crevices on exposed rock ledges or on quartzite gravel on hills mainly west of the mountains between Komaggas and the Orange River.

The slender grey stems bear leaves only for a very short period, so that this delicate plant is easily overlooked. The slender stems are superficially similar to those of C.pygmaea var. tenuis.

CAPE.-2816 (Oranjemund): Numees mountain (-BD), Tölken 3312 (BOL); Holgat River (-DB), Tölken 1857 (BOL). 2917 (Springbok): Augrabies (-AA), Hall 1362.4 (NBG): N. of Grootmis (-AC), Wisura 1303 (NBG); $48 \mathrm{~km} \mathrm{S.E.} \mathrm{of} \mathrm{Port}$ Nolloth (-AC). Acocks 14235 (PRE); $46 \mathrm{~km} \mathrm{E.} \mathrm{of} \mathrm{Port} \mathrm{Nol-}$ loth (-AD), M. Schlechter sub SUG 6870 (BOL); Ratelpoort (-BD), Litrlewood sub (NBG) 43469 (NBG); Komaggas (-CD), Tölken 2026 (BOI).

5. Cotyledon viridiflorum Toelken, sp. nov. a $C$. fragile petalis pubescentibus intra et extra et foliis dorsoventraliter complanatis glabrescentibus differt.

Fruticuli basis tuberosis, ramis paucis succulentis usque ad $35 \mathrm{~cm}$ longis, erectis, tectis pilis grandulosis glabrescentibus. Folia alterna, oblanceolata vel elliptica, $2-4 \mathrm{~cm}$ longa, $0,8-1 \mathrm{~cm}$ lata, cuneata, plerumque apicibus obtusis, dorsiventraliter complanata et leviter sulcata supra, tecta pilis glandulosis vel glabrescentia, succulenta, viridia. Inflorescentia thyrsus spiciformis (1-) 3-5 floribus, pedunclo $0,8-4 \mathrm{~cm}$ longo et pedicello glabro $0.5-1(-2,5) \mathrm{cm}$ longo, bracteatis squamosis. Sepala triangulari-lanceolata, 0, 5-0,6(-1) $\mathrm{cm}$ longa, acuta, tecta pilis glandulosis patentibus, succulenta, viridia. Petala oblonga, $2,4-2,6 \mathrm{~cm}$ longa, acuta, connata in tubo $1,8-2 \mathrm{~cm}$ longo, apicibus recurvis, tecta pilis plus minusve glandulosis intra et extra, leviter succulenta, viridia vel flavovirentia. Stamina 1,4-1,9 cm longa, antheris nigris $0,4-0,6 \mathrm{~cm}$ longis, filamentis pilis patentibus et saepe flexibus infra antheras. Squamae oblongae, 0,1-0,12×0,03-0,05 $\mathrm{cm}$, leviter emarginatae, succulentae, flavae. Carpella $1,2-1,5 \mathrm{~cm}$ longa, ovariis gracilibus gradate constrictis ad stylos erectos stigmatibus terminalibus; ovarium 8-12 ovulis elongato-ovatis porcis verticalibus.

TyPE: Cape, near Modderfontein, Tölken 5327 (PRE, holo!).

Shrublet with tuberous bases, with few brittle fleshy branches up to $35 \mathrm{~cm}$ long, erect, covered at first with glandular hairs, later glabrescent. Leaves alternate, oblanceolate to elliptic, $2-4 \mathrm{~cm}$ long, $0,4-1 \mathrm{~cm}$ broad, each with cuneate base and obtuse apex, dorsiventrally compressed and slightly grooved above the central vein, covered with glandular hairs when young becoming glabrous later. Inflorescence a spike-like thyrse with (1-) 3-5 flowers, with peduncle $0,8-4 \mathrm{~cm}$ long and pedicels $0,5-1(-1,5) \mathrm{cm}$ long, with scale-like bracts. Sepals triangular-lanceolate, 0,5-0,6 (-1) cm long, acute covered with spreading glandular hairs, succulent, green. Petals oblong 2,4-2,6 cm long, acute, fused into a tube $1,8-2 \mathrm{~cm}$ long, with apices recurved or recoiling, covered with recurved hairs, more or less glandular on the outside and inside, slightly fleshy, yellowish-green. Stamens 1,4-1,9 cm long, with black anthers $0,4-0,6 \mathrm{~cm}$ long, filaments with spreading hairs and often with right-angled outward bend below anthers. Squamae oblong $0,1-0,12 \times$ $0,03-0,05 \mathrm{~cm}$, slightly emarginate fleshy, yellow. Carpels with slender ovaries gradually constricted into erect styles with terminal stigmas; ovary with 8-12 ovules with vertical ridges. Like $C$. fragilis and $C$. vetricosa, this species grows in the shade of overhanging rocks and usually on the south aspect of mountains.

CAPE.-2817 (Vioolsdrif): near Modderfontein (-CC), Tölken 5327 (PRE).

6. C. hallii Toelken, sp. nov, a $C$. pearsonio habitato erecto-fastigiato et usque ad $40 \mathrm{~cm}$ alto, foliorum cicatricibus paene indistinctis et floribus erectis differt.

C.pearsonii sensu Jacobsen, Hand, Succ. Pl. 1: 289, fig. 286 (1960): Sukk. Lex. 135, t. 40,5 (1970), non Schonl. C racemosa sensu Friedr. in Prodr. FI. S.W. Afr. 52: 10 (1968), non Harv.

Fruticuli perennes caulibus succulentis usque ad 5 $\mathrm{cm}$ in diametro et leviter ventricosis ad basim, multiramosi et ramis erectis vel paene fastigiata. Folia alterna, lineari-lanceolata, $0,8-3,5 \mathrm{~cm}$ longa, $0,3-$ $0,5 \mathrm{~cm}$ lata, acuta, teretia vel interdum sulcata supra, sparsim tecta pilis glandulosis sed glabrescentia, viridia vel glaucescentia. Inflorescentia thyrsus 1-4 monochasiis, pedunculo lignescente $1,5-3,5 \mathrm{~cm}$ longo, pedicello tenace $1-3 \mathrm{~cm}$ longo tecto pilis plandulosis, bracteatis foliiformibus. Sepala triangularia, $0,4-0,9 \mathrm{~cm}$ longa, acuta, tecta pilis glandulosis patentibus, succulenta, viridia. Petala oblonga, 1,7-2 cm longa, plerumque acutissima, connata in tubo $1-1,4$ $\mathrm{cm}$ longo, apicibus recurvis sed erectis in fructu, tecta pilis glandulosis patentibus extus et pilis sparsis tenuibus intus, leviter succulenta, viridia vel flavo-viridia. Stamina 1,6-2 cm longa, antheris $0,3-0,5 \mathrm{~cm}$ longis, filamentis paene glabris et plerumque flexibus infra antheras. Squamae oblongae 0,12-0,15×0,04-0,06 $\mathrm{cm}$, emarginatissimae, succulentae ad basim, flavae. Carpella ovariis gracilibus gradate constrictis ad stylos erectos stigmatibus terminalibus; ovarium $30-36$ ovulis ovatis sed latioribus ad lateres et papillosis plerumque serialis.

TyPE: Cape, De Hoop, H. Hall 1300 (NBG, holo!).

Perennial shrublet with fleshy stems up to $5 \mathrm{~cm}$ in diameter and slightly swollen towards the base, much branched and branches erect and almost fastigiate. Leaves alternate, linear-lanceolate, $0,8-3,5 \mathrm{~cm}$ long, $0,3-0,5 \mathrm{~cm}$ broad, acute, terete or sometimes with a groove on the upper surface, sparsely covered with glandular hairs but becoming glabrous, green or yellowish-green. Inflorescence a thyrse with one to several monochasia, with glandular rarely glabrescent peduncle $1,5-3,5 \mathrm{~cm}$ long and glandular pedicels $1-3 \mathrm{~cm}$ long, with leaf-like bracts. Sepals triangular $0,6-0,9$ $\mathrm{cm}$ long, acute, covered with stout spreading glandular hairs, fleshy, green. Petals oblong, 1,7-2 cm long, usually very acute, fused into a tube $1-1,4 \mathrm{~cm}$ long, with apices recurved but straightened out again when fruiting, covered with glandular hairs along the outside and in particular the centre of each petal, with scattered fine hairs or rarely papillose on the inside, slightly fleshy, green to yellowish-green. Stamens $1,6-2 \mathrm{~cm}$ long, with anthers $0,3-0,5 \mathrm{~cm}$ long. with filaments almost glabrous and usually with a rightangled outward bend below the anthers. Squamae oblong, $0,12-0,15 \times 0,04-0,06 \mathrm{~cm}$, strongly emarginate, succulent towards the base, yellow. Carpels with slender ovaries gradually constricted into erect styles and with terminal stigmas; ovary with $30-45$ elongate ovules which are usually dumbell-shaped and with papillae often arranged in irregular rows.

This species occurs on rocky slopes in the mountains on either side of the Orange River of Vioolsdrif.

S.W.A.-2717 (Chamaites): near Aiais (-CD), Pillans 658 (BOL). 2816 (Oranjemund): Kahanstal (-BB), Dinter 8152 (BOL, K, PRE, SAM); De Winter \& Giess 6360 (PRE).

CAPE_-2817 (Vioolsdrif): De Hoop (-AA), Hall l320 (NBG); $20 \mathrm{~km} \mathrm{E}$ of Eksteenfontein (-CD), Leistner 3373 (PRE): $32 \mathrm{~km}$ S.W. of Vioolsdrif (-CD), Werger 405 (PRE). 
7. Cotyledon tomentosa Harv. in Fl. Cap. 2: 373 (1862); Schonl. in Rec. Albany Mus. 3: 146 (1915). Type: Cape, between Groot River and Trumpeter's Poort, Zeyher 1085 (S, holo!).

\section{subsp. tomentosa.}

C. tomentosa Harv. in Fl. Cap. 2: 373 (1862). C. ladismithiensis sensu Boom in Succulenta, Amst. (1958) 17; sensu Jacobsen, Handb. Succ.Pl. 1:284, fig. 278 (1960); Sukk. Lex. 134, T.39, 1 (1970), non V.Poelln.

Shrublets with slender branches, much branched. Leaves oblanceolate $1,5-2,5(-3,5) \mathrm{cm}$ long, $0,8-1,4$ $(-1,7) \mathrm{cm}$ broad, with $3-5(-10)$ apical teeth, more or less dorsiventrally compressed.

C. tomentosa is a little known species, which is poorly represented in herbaria and at known localities one finds only a few plants. However, the main obstacle in interpreting the identity of $C$. tomentosa was that Harvey did not mention in his description the three distinct teeth at the apex of the leaves. The type locality given by Zeyher was rather vague, but it must be sought somewhere east of Steytlerville, which lies on the Gamtoos River (alias Groot River). The plant was recently collected in the mountains just north of Steytlerville (Tölken 1778).

Then $C$. heterophylla Schoenl. non Roxb. was described from the vicinity of Ladismith, but being a later homomym it must be replaced by the name C. ladismithiensis V.Poelln. The latter taxon is here considered to be a separate subspecies of C.tomentosa, which is distinguished from the typical subspecies by its longer almost terete leaves as described below. The number of teeth on the leaves varies greatly on the same and different plants, and juvenile plants of both subspecies seem to have leaves with 1-3 teeth. The leaves of juvenile plants and of plants of the subsp. tomentosa growing in deep shade are villose, while those of the subsp. ladismithiensis are tomentose, but no seedlings have been seen.

Subsp. tomentosa has been recorded from near Calitzdorp, Willowmore and Steytlerville, where it occurs on the slopes of sheltered kloofs. Plants of the subsp. ladismithiensis occur on rock outcrops between Laingsburg and the northern slopes of the Langeberg near Muiskraal.

subsp. ladismithiensis (V.Poelln.) Toelken, comb. nov. et stat. nov.

C.ladismithiensis V. Poelln. in Jahrb. Deutsch.Kakt. Ges. 1: 94 (1936); in Fedde Repert. 42: 40 (1937). Type: Cape, between Ladismith and Laingsburg, E.Pillans sub N.S. Pillans 968 (GRA, holo!; BOL). C. heterophylla Schoenl. in Rec. Albany Mus. 2: 150 (1907), non Roxb. (1814); in Rec. Albany Mus. 3: 146 (1915). Type: same as for C.ladismithiensis.

Shrublet with rigid spreading branches, little branched. Leaves oblong-elliptic (3-) 3,5-5,5(-8) cm long, $0,8-1,2 \mathrm{~cm}$ broad, with $1(-3)$ apical teeth, usually almost terete and only occasionally the upper surface is compressed.

CAPE.-2033 (Montagu): Anysberg (-DB), Stokoe 8708 (BOL); western Touwsberg (-DB), Wurts 1467 (NBG). 2133 (Ladismith): Ladismith (-AD), Joubert s.n. (BOL); Huisrivierpas (-BC), Marloth 13128 (PRE); Ockertskraal (-CA), Hall 1224 (NBG); $16 \mathrm{~km}$ S. of Ockertskraal (-CA), Tölken 1699 (BOL); Adamskraal (-CC), Muir sub BOL 30962; Muiskraal (-CC), Muir sub Marloth 12185 (PRE); between Laingsburg and Ladismith, E. Pillans sub N.S. Pillans 968 (BOL, GRA).

\section{UITTREKSEL}

$V y f$ nuwe species en een variëteit word beskryf en die nuwe kombinasie Cotyledon tomentosa Harv. subsp. ladismithiensis (V.Poelln.) Toelken word teweeggebring. Die volgende nuwe name is gepubliseer: C. sulphurea Toelken, C. occultans Toelken, C. similis Toelken, C. viridiflorum Toelken, C. hallii Toelken en C. pygmaea Barker var. tenuis Toelken. 